\title{
PENGELOLAAN PROGRAM INDUKSI GURU PEMULA (PIGP) DI SMP NEGERI 3 KUNDURAN BLORA
}

\author{
Sugiyarti dan Bambang Sumardjoko \\ Magister Administrasi Pendidikan Sekolah Pascasarjana \\ Universitas Muhammadiyah Surakarta \\ Sugiyartipasca1975@gmail.com
}

\begin{abstract}
The method used in the study was a qualitative research for this study aimed to describe the planning, implementation and evaluation of programs induction of beginning teachers (PIGP) in SMP Negeri 3 Kunduran. Data were collected by interview, observation and documentation. Divalidas validity of the data with data triangulation. Data analysis techniques with data collection, data reduction, data presentation and conclusion. The results of this study started that the planning PIGP planned jointly by the school principal and guidance counselor. The planning of program was made in firstmonth of program. Implementation PIGP in the second to the ninth month, in which the novice teachers implement instructional tahab accompanied by a tutor with evaluation performed at least once a month by the supervising teacher. The final evaluation was conducted in the tenth and eleventh by a guidance counselor, school principals and supervisors to determine the continuation of a career profession beginner teachers.
\end{abstract}

Keywords: Induction, News teacher, Guidedance teacher.

\begin{abstract}
Abstrak. Metode penelitian yang digunakan pada penelitian ini adalah penelitian kualitatif. Penelitian ini bertujuan untuk mendeskripsikan perencanaan, pelaksanaan dan evaluasi program induksi guru pemula (PIGP) di SMP Negeri 3 Kunduran. Metode pengumpulan data dengan wawancara, observasi dan dokumentasi. Keabsahan data menggunakan trianggulasi data. Teknik analisis data dengan analisis interaktif ang meliputi tahapan pengumpulan data, reduksi data, penyajian data dan penarikan kesimpulan. Hasil penelitian ini menyatakan bahwa perencanaan PIGP direncanakan secara bersama oleh kepala sekolah dan guru pembimbing. Kepala sekola membuat analisis kebutuhan dan ditindak lanjuti oleh guru pembimbing menjadi prioritas pembimbingan pada bulan pertama program. Pelaksanaan PIGP pada bulan kedua sampai dengan bulan kesembilan dimana pada tahab pelaksanaan guru pemula melaksanakan pembelajaran didampingi guru pembimbing dengan evaluasi dilakukan minimal satu kali tiap bulan oleh guru pembimbing. Evaluasi akhir dilaksanakan pada bulan kesepuluh dan kesebelas oleh guru pembimbing, kepala sekolah, dan pengawas untuk menentukan kelanjutan karir keprofesian guru pemula.
\end{abstract}

Kata kunci: guru pembimbing, guru pemula, induksi.

\section{Pendahuluan}

Kemakmuran suatu bangsa berkaitan erat dengan kualitas atau mutu pendidikan.
Bahkan bangsa-bangsa yang berhasil mencapai kemakmuran dan kesejahteraan dewasa ini adalah bangsa-bangsa yang 
melaksanakan pembangunan berdasarkan strategi pengembangan sumber daya manusia. Artinya, melaksanakan pembangunan nasional dengan menekankan pada pembangunan pendidikan untuk peningkatan kualitas sumber daya manusia.

Pendidikan akan berhasil dengan baikjika didukung oleh semua faktor pendukungnya antara lain: sarana prasana, strategi, kurikulum, peran orang tua, iklim sekolah maupun keterlibatan siswa. Sebagian besar penelitian mengenai keberhasilan pendidikan menyebutkan bahwa kualitas guru dan kemampuan pedagogisnya adalah faktor yang paling penting dalam mempengaruhi prestasi akademik yang dicapai oleh siswa. Guru dengan segala kemampuannya yang meliputi kompetensi pedagogis, profesional, sosial dan individual merupakan ujung tombak pendidikan, pasalnya apapun sistemnya, software dan hardwarenya, pendidikan suatu bangsa tanpa didukung oleh kualitas dan profesionalisme guru sangatlah kecil kemungkinan dapat mencapai tujuan yang telah ditetapkan ( Wibowo A, 2012: 5).

Guru memang bukan satu-satunya faktor penentu keberhasilan pendidikan, ada banyak faktor lain yang juga ikut menentukan, tetapi proses pembelajaran sebagai titik sentral pendidikan sangat tergantung pada peran seorang guru. Pada proses pembelajaran guru memiliki andil sangat besar, sebagai inovator, fasilitator dan motivator. Guru harus bisa mengemas pembelajaran menjadi kegiatan yang menarik dan menggembirakan bagi para peserta didik. Keprofesionalan seorang guru akan terlihat pada kemampuannya dalam mengemas proses pembelajaran, dari mulai merencanakan, melaksanakan dan mengevaluasi pembelajaran.

Guru yang profesional dapat dihasilkan melalui berbagai upaya seperti pelatihan, seminar, lokakarya, bahkan menyekolahkan guru pada tingkat pendidikan yang lebih tinggi. Banyak upaya yang telah dilakukan pemerintah untuk meningkatkan mutu guru, berbagai macam diklat telah diadakan dari tingkat kabupaten hingga nasional, pemberian subsidi untuk pelaksanaan kegiatan pada kelompok kerja guru dari mulai kelompok kerja guru (KKG) untuk guru pengajar tingkat SD hingga Musyawarah guru mata pelajaran (MGMP) untuk para guru pengajar tingkat SMP dan SMA/SMK dirasa masih belum bisa meningkatkan kompetensi para guru.

Kenyataannya sebagian besar guru di Indonesia dinyatakan tidak layak mengajar. Persentase guru menurut kelayakan mengajar dalam tahun 2002-2003 di berbagai satuan pendidikan sbb: untuk SD yang layak mengajar hanya $21,07 \%$ (negeri) dan $28,94 \%$ (swasta), untuk SMP 54,12\% (negeri) dan 60,99\% (swasta), untuk SMA 65,29\% (negeri) dan $64,73 \%$ (swasta), serta untuk SMK yang layak mengajar 55,49\% (negeri) dan 58,26\% (swasta) (Wibowo,A. 2012: 18).

Berdasarkan hasil Uji Kompetensi Guru yang dilaksanakan pada tahun 2015 didapatkan hasil secara nasional sebagai berikut, nilai maksimal 100 , nilai minimal 10 , rata rata 53,05 dengan standart deviasi 12,56 dari jumlah sampel keseluruhan adalah 2.430.427 guru. Dari 34 provinsi se Indonesia hanya tujuh provinsi saja yang mencapai nilai di atas nilai rata rata, yaitu Jawa Barat, Jawa Tengah, DIY, DKI Jakarta, Bali Jawa Timur dan Bangka Belitung (Kemdikbud.go.id. 2015). Nilai rata rata itu tentu saja masih jauh dari target pemerintah yang mengharapkan semua guru dapat mencapai nilai 80 .

Selain rendahnya mutu guru permasalahan lain adalah pada kurun waktu 2009 - 2019 terdapat 451.767 guru yang akan masuk masa pensiun, tentu saja dibutuhkan guru baru untuk mengisi kekosongan ini. Jika seorang guru baru / pemula mengajar tiga puluh siswa maka akan ada 13.553.010 siswa yang mengalami proses pembelajaran bersama dengan guru pemula. Maka diperlukan program pembimbingan pada guru guru pemula ini supaya dapat menggantikan posisi guru guru yang telah pensiun dengan kompetensi yang setara bahkan melebihi dari para guru yang pensiun karena faktor usia tentu saja mempengaruhi 
kinerja. penyelenggaraan program induksi guru pemula menjadi sangat penting untuk menjamin mutu guru tetap profesional yang berdampak pada mutu pendidikan pada akhirnya (www.SIMNUPTKgoogleweblight. com)

Program pembimbingan untuk guru pemula ini dicanangkan oleh pemerintah sejak tahun 2008 dengan nama Program Induksi Guru Pemula atau disingkat PIGP. Program ini baru dilaksanakan di kabupaten Blora pada tahun 2015 termasuk SMP Negeri 3 Kunduran yang pada tahun 2015 mendapatkan tiga guru CPNS juga menerapkan program ini untuk membantu guru pemula lebih cepat menyesuaikan diri dan lebih cepat mencapai keprofesionalan di bidangnya. Dua dari tiga guru pemula memiliki kualifikasi ijasah yang tidak sesuai dengan mata pelajaran pada SK pengangkatannya. Tentu saja para guru pemula ini mengalami kesulitan untuk mengajarkan mata pelajaran yang bukan kualifikasi ijasahnya. Progaram induksi ini menjadi sangat penting bagi guru pemula di SMP Negeri 3 Kunduran ini untuk membantu kelancaran dalam proses pembelajaran setiap harinya.

Program pembimbingan guru pemula ini tentu harus direncanakan dengan baik dan matang kemudian dilaksanakan dengan evaluasi yang baik. Bagaimana Program Induksi Guru Pemula (PIGP) ini direncanakan kemudian dilaksanakan dan dievaluasi di SMP Negeri 3 Kunduran menjadi tujuan pemelitian ini dilakukan. Penelitian ini akan mendeskripsikan proses proses pada PIGP yang meliputi perencanaan, pelaksanaan dan evaluasi.

\section{Metode}

Jenis penelitian ini adalah penelitian kualitatif karena penelitian ini berusaha memberikan gambaran sedetail mungkin mengenai pengelolaan PIGP di SMP N 3 Kunduran. Dengan jenis penelitian kualitatif diharapkan menghasilkan deskripsi analitik tentang fenomena fenomena yang secara murni bersifat informatif dan berguna bagi masyarakat, peneliti, pembaca dan juga partisipan (Sukmadinata, 2007: 107).

Desain penelitian yang digunakan pada penelitian ini adalah desain penelitian etnografi. Desain penelitian etnografi menjelaskan secara menyeluruh tentang kompleksitas kehidupan berkelompok (Sukmadinata, 2010: 107). Kompleksitas kehidupan berkelompok pada penelitian ini meliputi kegiatan kegiatan yang dilakukan oleh semua yang berperan dalam program induksi guru pemula, seperti kegiatan yang dilakukan guru pemula, guru pembimbing, kepala sekolah maupun pengawas sekolah.

Menurut Moleong (2012: 157) Sumber data utama dalam penelitian kualitatif adalah kata kata dan tindakan, sedangkan dokumen dan selebihnya adalah data tambahan. Kata dan tindakan dari orang orang yang diamati kemudian direkam maupun dicatat dalam bentuk tulisan merupakan data utama. Wawancara dilakukan dengan menggabungkan usaha bertanya, melihat, mendengar pada informan untuk mendapatkan data utama.

Teknik pengumpulan data menggunakan teknik wawancara, observasi dan dokumentasi. Data diperoleh dari nara sumber yaitu tiga orang guru pemula, tiga orang guru pembnimbing, seorang kepala sekolah, seorang pengawas dan dua orang wakil kepala sekolah. Pada penelitian ini menggunakan uji keabsahan data dengan menggunakan tiga teknik, a) membandingkan hasil wawancara dengan hasil observasi, b) membandingkan data hasil wawancarra dari satu sumber dengan sumber yang lain, c) membandinglan hasil wawancara dengan data dokumentasi.

Teknik analisa data menggunakan teknik flow model of analisys di mana reduksi data dimulai sejak pengumpulan data belum berlangsung, dan diteruskan pada saat pengumpulan data dilakukan. Pengumpulan data, reduksi data, sajian data dan penarikan kesimpulan ini terjalin bersama dan terus menerus (Sumardjoko, B. 2015: 34). 


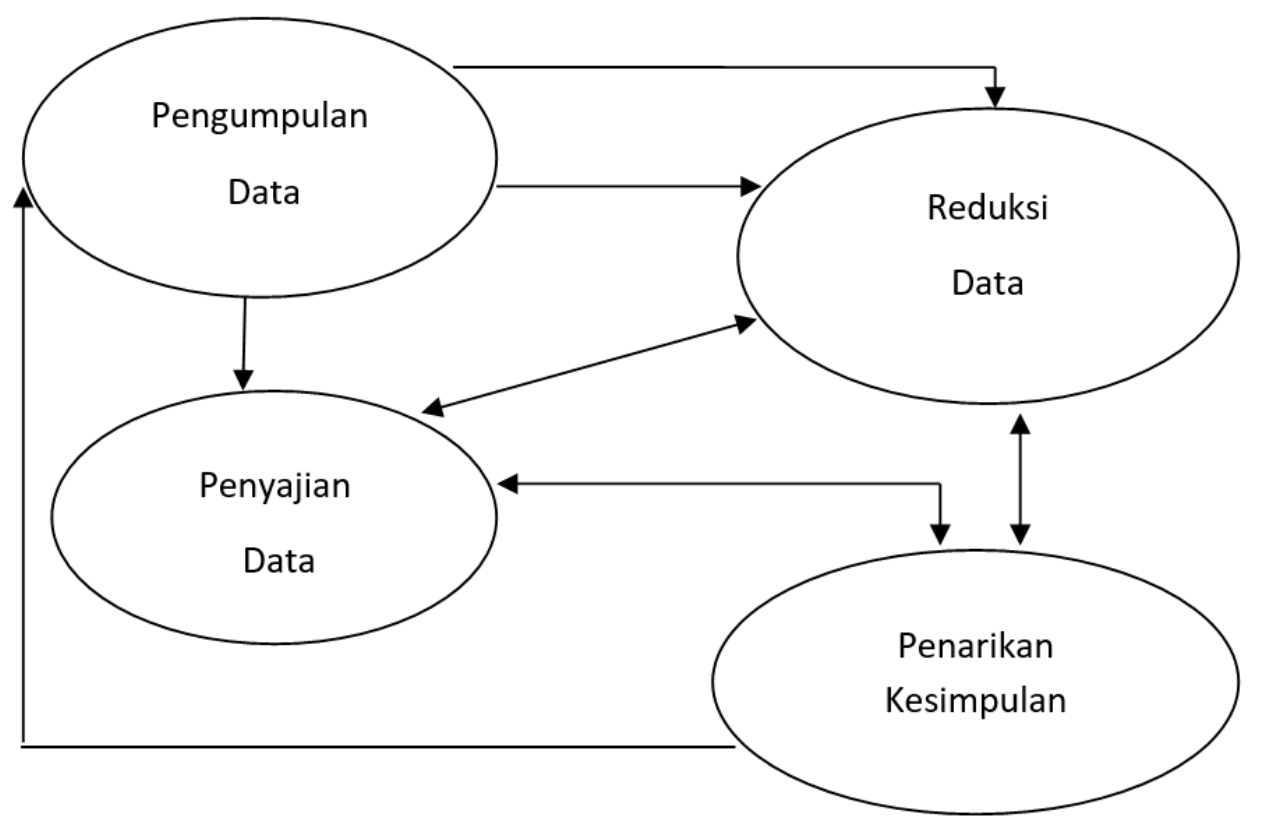

Gambar 3.4 Komponen dalam analisis data (Interactive Model)

Sumber : Sugiyono (2010: 338)

\section{Hasil dan Pembahasan}

\section{A. Perencanaan PIGP di SMP Negeri 3 Kunduran}

Perencanaan program induksi guru pemula di SMP Negeri 3 Kunduran dibuat secara bersama sama oleh kepala sekolah dan pengawas sekolah. Kepala sekolah membuat analisis kebutuhan untuk guru pemula melalui wawancara dengan para guru pemula. Analisis kebutuhan yang dibuat oleh kepala sekolah kemudian diserahkan kepada guru pembimbing untuk ditindak lanjuti menjadi skala prioritas pembimbingan.

Kepala sekolah menjelaskan bahwa kebutuhan tiap guru pemula berbeda. Ada guru pemula yang lemah pada penguasaan dan penerapan model pembelajaran. Guru pemula yang lain lemah pada penerapan teknik bertanya dan penanganan siswa secara perorangan . Secara umum kelemahan ketiga guru pemula adalah kurangnya kemampuan bertanya atau teknik bertanya dan penggunaan bahasa indonesia yang baik dan benar pada proses pembelajaran. Guru pemula masih sering berkomunikasi menggunakan bahasa jawa sebagai bahasa daerah/ bahasa Ibu.

Guru pembimbing kemudian membuat skala prioritas pembimbingan berdasarkan data analisis kebutuhan guru pemula dari kepala sekolah. Selain itu guru pembimbing dalam satu bulan pertama PIGP juga melakukan komunikasi dengan guru pemula untuk mengetahui kompetensi apa saja yang masih dirasa lemah oleh guru pemula.

Guru pemula mapel IPS mengalami kesulitan dalam penyampaian materi IPS dan pembuatan alat penilaiannya. Hal ini dikarenakan pembelajaran IPS dalam model tematik antara sejarah, ekonomi dan geografi. Guru pembimbing memasukkan hal ini dalam prioritas pembimbingan. Pada tahap perencanaan ini guru pemula membuat Rencana pembelajaran untuk satu tahun pelajaran, sedangkan guru pembimbing mulai membimbing dengan meminjamkan file perangkat pembelajaran ataupun berdiskusi langsung dengan guru pemula.

Guru pembimbing tidak serta merta merasa lebih tahu dan lebih profesional daripada guru pemulanya. Guru pembimbing lebih mengedepankan prinsip kemitraan dalam PIGP ini. Pada saat guru pemula mengalami kesulitan dalam pembuatan rubrik penilaian, maka dirinyapun berusaha membantu dengan berdiskusi bersama sama untuk menentukan aspek apa saja bisa dijadikan acuan penilaian 
produk. Contohnya pada materi menggambar peta. Hasil diskusinya menyatakan bahwa aspek yang dinilai antara lain, skala, warna, indeks, judul, tahun, simbol. Dari berbagai aspek itu kemudian diambil 4 aspek saja sebagai aspek penilaian.

Pada program Induksi ini guru pembimbing atau mentor memang sangat perlu untuk terus belajar untuk memperluas pengetahuan dan mengikuti perkembangan materi pembelajaran. Pendampingan dan pembimbingan dalam perencanaan pembelajaran seperti yang dialami oleh guru pemula di atas juga pernah dikemukakan oleh Moir, (2009).

Pada penelitian Moir di Amerika, kegiatan mentoring dilaksanakan tidak hanya pada kemampuan pedagogik saja tetapi juga pada kemampuan akademik. Seorang mentor menurut Moir harus mampu berdiskusi dengan guru pemula dari mulai cara mengajar sampai apa yang diajarkan, sehingga guru pemula dapat mengajar dengan nyaman pada tahun pertamanya menjadi seorang guru.

Dukungan yang diberikan oleh guru pembimbing mapel IPS kepada guru pemula sesuai dengan yang telah diteliti oleh Israel, Maya dkk (2014). Penelitian Israel Maya menerangkan bahwa fungsi mentoring harus mampu memberikan dukungan karir dan dukungan psikososial. Ia menggambarkan fungsi dukungan sebagai membantu guru baru mempelajari segala sesuatu. Guru mentor menavigasi langkah langkah kemajuan guru pemula. Dukungan psikososial termasuk pemodelan peran, dan konseling melalui berbagai dilema yang terjadi selama program. Dalam mentoring pendidikan khusus, program induksi ini mendukung karir dalam menangani kebutuhan profesional dan instruksional set baru, seperti penjadwalan, sesuai dengan program pendidikan individual, mengelola perilaku, memfasilitasi strategi pembelajaran, dan berkolaborasi dengan para educators, orang tua, dan rekan Psikososial mendukung mentoring, bagaimanapun, dapat mengatasi kebutuhan emosional set baru dan mungkin termasuk menyediakan set baru dengan pemahaman tentang menjadi seorang guru baru dan bekerja melalui kecemasan yang berhubungan dengan pekerjaan

Penelitian Israel, Maya (2014) melibatkan lima mentor dan 16 guru pemula menyatakan bahwa dukungan emosional dari guru mentor penting dalam menunjang profesionalitas seorang guru pemula. Sebagian guru baru bahkan menyatakan bahwa dukungan emosional berupa motivasi dan penguatan justru lebih dibutuhkan daripada dukungan profesional. Hal ini dikarenakan seorang guru baru merasa tertekan pada saat diawasi oleh guru mentor. Guru baru merasa bahwa guru mentor mencari kelemahannya dalam mengajar, sehingga mereka menjadi depresi. Pada saat seperti itulah diperlukan pendekatan emosional dari guru mentor dengan guru baru supaya guru baru tetap dapat merasa nyaman dengan kehadiran guru mentor.

\section{B. Pelaksanaan PIGP di SMP Negeri 3 Kunduran}

Guru pemula mapel Bahasa Indonesia tadinya mengajar Seni Budaya dan Ketrampilan (SBK) padahal kualifikasi pendidikannya adalah Sarjana Ekonomi. Pada tahun 2015 mendapatkan pengangkatan dari formasi K2 sebagai guru CPNS mapel Bahasa Indonesia dan ditemptkan di SMP Negeri 3 Kunduran dengan syarat harus menempuh pendidikan S1 mapel bahasa Indonesia yang bisa ditempuh setelah mendapatkan pengangkatan menjadi PNS.

Kendala utama yang dirasakan oleh guru pemula mapel Bahasa Indonesia adalah variasi pada model pembelajaran. Pada tahap pelaksanaan Program Induksi Guru Pemula ini dirinya banyak dibimbing pada praktek pembelajaran dengan menggunakan model pembelajaran yang bervariasi. Model pembelajaran yang pernah dicobanya antara lain role playing, NHT, STAD, bermain peran dan beberapa model pembelajaran yang dimodifikasi oleh guru pembimbingnya. Beberapa kali guru pemula juga menyempatkan diri mengikuti pembelajaran di kelas yang diampu oleh 
guru prmbimbingnya untuk mendapatkan tambahan model pembelajaran.

Pada kelas yang diampu pembimbingnya, guru pemula mendapatkan tambahan model pemebelajaran yang disebut "Si kancil". Model pembelajaran "Si kancil" merupakan singkatan dari siapkan Kartu kecil. Pada materi bercerita, siswa memang diminta membaca sebuah cerita atau sinopsis, kemudian nanti siswa secara bergantian akan diminta untuk maju menceritakan kembali cerita yang telah dibacanya. Untuk memudahkan siswa dalam presentasi, maka siswa diminta menyiapkan kartu kecil untuk mencatat hal hal yang penting yang akan membantunya pada saat maju ke depan kelas.

Pada saat evaluasi guru pemula mapel bahasa Indonesia mendapatkan koreksi dan pembetulan dari pengawas sekolah mengenai model pembelajaran yang digunakan. Model pembelajaran yang digunakan adalah NHT tetapi pada saat terjadi diskusi antara siswa, guru masih mengajukan pertanyaan sehingga menururt pengawas sekolah hal itu justru tidak tepat. Guru seharusnya menjadi fasilitator dan motivator pada saat siswanya berdiskusi, guru jangan memberikan pertanyaan yang mengganggu jalannya diskusi siswa. Jika siswa telah selesai berdiskusi maka dibolehkan jika kemudian guru memberikan pertanyaan pertanyaan sebagai penguatan ataupun menggirirng siswa menarik kesimpulan.

Tindakan yang dilakukan oleh guru pemula bersama dengan guru pembimbingnya seperti yang dilakukan olehTommon, John (2010). Guru pembimbing harus memberikan layanan kepada guru pemula supaya guru pemula dapat tumbuh menjadi guru yang profesional. Guru pemula merasa telah banyak belajar baik dari guru pembimbing maupun arahan oleh pengawas.

Menurut Schuster, Dwight. dkk (2012), menyatakan bahwa semua yang berperan dalam sekolah harus mendukung keberhasilan guru baru. Guru pemula harus didukung baik oleh mentor Staf administrasi maupun kepala sekolah. Hal ini sama seperti tindakan yang dilakukan oleh Dwi Sulistiyorini. Guru pembimbing mapel bahasa indonesia ini membuka kelasnya pada guru pemula untuk memberikan kesempatan melihat langsung cara ia membawakan pembelajaran dengan model "Si Kancil"

Schuster, Dwight. dkk (2012), juga menyatakan bahwa keberhasilan guru pemula dalam tahun pertama mengajarnya bukan ditentukan oleh kapasitas individu. Ada banyak dukungan dari teman guru yang lain maupun kepala sekolah dan staf administrasi yang mendukungnya dengan memberikan motivasi dan perhatian. Guru baru lebih dimungkinkan untuk meninggalkan sekolah di mana mereka tidak cukup didukung baik oleh rekan guru maupun pihak sekolah yang lain. Sebagian besar dari mereka tidak puas dengan dukungan atau pelayanan dan kondisi staf administrasi di lingkungan kerjanya. Langkah selanjutnya yang diambil oleh Alighning University adalah membentuk tim khusus untuk menyiapkan guru baru sari tiga disiplin ilmu yang biasa disebut STEM (Sains, Teknik, Matematika).

Keterlibatan mentor seperti pada PIGP di SMP Negeri 3 Kunduran yang langsung membuka kelas untuk guru pemula pernah juga dilakukan oleh Hellen Laurie-ann. Dalam penelitisnnya, Hellen laurie-ann (2009) menyatakan bahwa ia dalam salah satu program mentoring yang ia terapkan salah satunya adalah melibatkan mentor secara langsung dalam pembelajaran guru pemula. Guru mentor memang memegang peranan yang kuat dalam kualitas guru pemula. Maka pemilihan guru mentor menjadi salah satu hal yang penting dalam program mentoring ini

\section{Evaluasi PIGP di SMP Negeri 3 Kunduran}

Evaluasi Program induksi dilakukan dengan melakukan observasi pada proses pembelajaran guru pemula. Observer melakukan penilaian pada lembar observer yang telah disediakan dengan aspek penilaian seperti penilaian Kinerja Guru setiap tahunnya. Penilaian meliputi empat 
kompetensi yaitu pedagogik, profesional, sosial dan kepribadian. Empat kompetensi pokok ini kemudian dijabarkan menjadi duapuluh indikator. Observer atau tim penilai adala kepala sekola, pengawas dan guru pembimbing.

Hasil observasi oleh tim penilai kemudian digabungkan menjadi satu nilai yang menjadi indikator keberhasilan program induksi guru pemula di SMP Negeri 3 Kunduran. Dari ketiga guru pemula semuanya mendapatkan nilai minimal B( Baik) sehingga pada taun berikutnya diajukan menjadi Pegawai Negeri Sipil Daerah Kabupaten Blora.

Rencana kepala sekolah berencana ke depannya akan mengadakan In House Training untuk memperluas Pemahaman bapak dan ibu guru mengenai teknik bertanya, penyusunan alat penilaian dan model pembelajaran yang komunikatif. Selain itu program sekolah untuk mengirinkan bapak Ibu guru pada forum musyawarah Guru Mata Pelajaran juga akan tetap dilaksanakan dalam rangka mendukung pengembangan diri guru.

Israel, Maya dkk (2014) mengemukakan bahwa ada tiga hal yang penting pada kegiatan mentoring. Kegiatan itu meliputi evaluasi pada program mentoring akan memberikan bimbingan untuk umpan balik mentor. Dukungan emosional dan dukungan profesional yang saling terkait, dimana dukungan emosional terjadi dalam konteks dukungan profesional. Sebagian besar guru baru tidak menunjukkan bahwa evaluasi terpengaruh pengalaman mentoring mereka.

Kebijakan kepala sekolah untuk mengadakan IHT ini sesuai dengan penelitian Shanks, R. (2012) yang menyatakan bawa kepala sekolah, pembuat kebijakan dan pemerintah daerah harus mendukung dan responsif terhadap pembelajaran dan pengembangan kebutuhan guru baru ketika menerapkan kebujakan program induksi guru baru.

Tommon, John (2010) menyatakan bahwa guru-guru baru akan segera membuat dampak pada pembelajaran dan kehidupan siswa mereka. Tapi siapa yang akan mendukung guru-guru baru? Akankah kami mengambil anak sapi yang baru disapih dan berharap untuk berkembang tanpa perawatan khusus dan perhatian? Tentu saja tidak! produsen yang baik tahu bahwa perawatan dan dukungan khusus diperlukan selama masa transisi stres ini. Mengapa kita tidak menawarkan tingkat yang sama perawatan dan dukungan untuk guru dimulai pada tahun-tahun pertama stres mengajar?. Guru muda telah menginvestasikan banyak waktu dan uang ke dalam mengejar pendidikan sebagai karier.

Shanks, R. (2012) juga menyatakan bahwa untuk lebih efektifnya program induksi guru pemula dan guru pembimbing perlu mendapatkan pengurangan beban mengajar. Sementara di Kabupaten Bloran pelaksanaan PIGP tidak mendapatkN pengurangan jam baik guru pemula maupun guru pembimbing sehingga proses pembimbingan dilakukan disela sela pembelajaran, bahkan juga terkadang pada saat jam pembelajaran. Beberapa kali dilaksanakan setelah jam pembelajaran berakhir. Guru pemula dan guru pembimbing harus pandai menyisihkan waktu untuk PIGP supaya tdak mengganggu jam pembelajaran.

Junaedhi, M (2015) dalam tesismya menyatakan bahwa terdapat kontribusi secara simultan antara program induksi guru pemula terhadap kinerja guru di Kabupaten Klaten dengan nilai koefisien determinasi(R2) sebesar54,5\% pada taraf signifikasi $\propto=0,000<0,05$, (2) terdapat kontribusi yang signifikan program induksi guru pemula terhadap kinerja guru dengan nilai kontribusi sebesar 21,4\%. Hasil penelitian Junaedhi dapat disimpulkan bahwa Program Induksi meningkatkan kinerja guru termasuk kinerja guru pemula. Hal ii dpat dimengerti karena guru pemula merasa terbantu dalam melaksanakan tugas tugasnya sebagai guru pemula dengan adanya program bimbingan yang diberikan oleh guru pembimbing. 


\section{Simpulan}

Perencanaan PIGP dilakukan oleh guru pemula, guru pembimbing, kepala sekolah dan pengawas dengan membuat kesepakatan kesepakatan untuk pelaksanaan program induksi guru pemula ini. Guru pemula dengan bantuan guru pembimbing juga menyiapkan perangkat pembelajaran untuk satu tahun pelajaran. Guru pembimbing dengan masukan dari kepala sekola membuat skala prioritas pembimbingan.

Pelaksanaan program pembimbingan dilakukan pada bulan kedua sampai dengan bulan kesembilan. Program pembimbingan dibuat untuk delapan bulan dengan minimal satu kali evaluasi tiap bulannya. Guru pemula melaksanakan pembelajaran dengan didampingi oleh guru pembimbing, pembelajaran dilakukan baik secara team teching maupun lesson study. Guru pembimbing melakukan pembimbingan dengan memberikan suport dan motivasi sehingga guru pemula bersemangat dalam pelaksanaan PIGP. Kepala sekolah menerima laporan pelaksanaan pembimbingan dari guru pembimbing secara periodik setiap bulan baik secara lisan maupun tertulis mengenai pelaksanaan Program. Kepala sekolah selain menerima laopran juga memantau jalannya pembimbingan guru pemula yang dilakukan oleh guru pembimbing dengan meninjau langsung jalannya pembelajaran pada kelas guru pemula.

Evaluasi PIGP dilakukan oleh guru pembimbing setiap satu bulan sekali dengan fokus penelitian yang telah disepakati bersama dengan guru pemula. Sedangkan kepala sekolah dan pengawas melakukan penilaian pada bulan ke sepuluh dan ke sebelas untuk mengetahui kelayakan guru pemula naik jenjang menjadi PNS. Evaluasi dilakukan dengan pembelajaran model lesson study, dimana digunakan kata pembelajaran kita atau pembelajaran bersama sehingga guru pemula merasa nyaman dan tidak merasa dihakimi.

\section{Daftar Pustaka}

Algozzine, Bob. 2007. Beginning Teacher's perseftions of their Induction Program Experience. The clearing House. Vol.80.(3): 137-143

Dirjen peningkatan mutu PTK kementerian pendidikan nasional. 2010. Modul Program Induksi Guru Pemula (PIGP) bagi guru pembimbing. Jakarta : Dirjen Peningkatan mutu pendidik dan tenaga pendidikan kementerian pendidikan Nasional.

Depdiknas Dirjen Dikdas, 2003, Guru di Indonesia. Pendidikan, pelatihan dan perjuangan sejak zaman kolonial hinga era reformasi. Jakarta: Departemen Pendidikan Nasional Dirjen Dikdas Direktoral tenaga pendidikan.

Fraenkel and Wallen. 2015. How to Design and Evaluate Research in Education, ninth edition. New York: McGraw-Hill International Edition.

Furqon, M. 2010. Guru Sejati Membangun insan berkarakter kuat dan cerdas. Surakarta: Yuma pustaka

Ghony, MD dan Al Manshur, F. 2012. Metodologi Penelitian Kualitatif. Jokjakarta: Ar-Ruz Media.

Hallam,P.,dkk. 2012. Two Contrasting Models for Mentoring as They Affect Retention of Beginning Teachers. National Association of Secondary Schoo 1 Principals. NASSP Bulletin. Vol.96.(3): 243-278

Hellsten, L M. 2009. Teacher Induction: Exploring Beginning Teacher Mentorship. Canadian Journal of Education. Vol. 32.(4): 703-733

Hobson, A J. 2013. Judgementoring and other threats to realizing the potential of school-based mentoring in teacher education. Maderez Anggi.International Journal or mentoring 
Coachng in Education. Vol.2.(2): 89-108

Junaedi.M. 2015. Tesis Kontribusi Program Induksi Guru Pemula, Kompetensi Pedagogis dan Lingkungan kerja terhadap kinerja Guru Pemula di Kabupaten Klaten. UMS: Tesis Universitas Muhammadiyah Surakarta

Langdon, F; Ward, L. 2015. Educative mentoring: a way forward. International Journal of Mentoring and Coaching in Education Vol.4.(4) : 240-254.

Liliana, E. 2014. The process of induction in a coaching version: The 10th International Scientific Confernce and sofware for education Bucharest. Vol. 10.(24): 154-167

Mary C. 2000 . Making time for teacher induction : A lesson fron the New Zealand model, The Clearing House Vol.73.(6 ): 319-330.

Maya, I; Kamman, ML; McCray, E. 2014. Profesional Assistance, Emotional Suport, and evaluation. Exceptional Children Vol. 81.(1) : 45-63.

Moir, E. 2009. Acceleting teacher effetiveness: Lessons Learned from Two Decade of New Teacher Induction. Phi Delta Kappan. Vol.91.(2): 14-19

Moleong, LJ. 2012. Metodologi Penelitian Kualitatif. Bandung: Remaja Rosdakarya

Pirkle, SF. 2011. Stemming the Tide: Retaining and Supporting Science Teachers.

Science Educator Vol.20.(2) : 42-46.

Priyambodo, RH. 2010. 1,3 guru belum layak mengajar. Diambil dari http:// www.antaranews. com/berita/176844/13-juta-guru-belum-layak-mengajar. Diakses 10 September 2016

Schuster,D. 2012. Aligning University Based Teacher Preparation and New STEM Teacher Suport. Science Educator. Vol 20.(3): 39-44

Shanks, R. 2012. Apprenticeship of new teachers during their induction year. Higher education skill \& works based learning.Vol.2.(3): (256-270)

Stobaugh, R. 2014. Preparing for succes.Principal Leadership Vol.14.(7) : 36-40.

Sudrajat, A. 2010. Sekilas tentang program Induksi Guru Pemula (PIGP). Diambil dari https://akhmadsudrajat.wordpress.com/.../sekilas-tentang-program-induks... Diakses 10 September 2016

Sugiyono. 2012. Metode Penelitian Pendidikan Pendekatan Kuantitatif, kualitatif, dan R\&D. Bandung: Alfabeta.

Sukmadinata, N. S. 2012. Metode Penelitian Pendidikan. Cetakan kedelapan. Bandung: PT Remaja Rosdakarya.

Sukmadinata, NS. 2010. Metode penelitian pendidikan. Bandung: PT Remaja Rosdakarya

Sumardjoko, B. 2015. Diktat Perkuliahan, Metodologi Penelitian Kualitatif. Surakarta: UMS

Tummons, J. 2010. Care and Feeding of young teacher: Missouri's Model for Beginning Teacher Succes. The Agricultur Education Magazine. Vol. 82.(6): 16-31

Undang-Undang Nomor 14 Tahun 2005 tentang Guru dan Dosen

Wibowo, A. 2012. Menjadi Guru Berkarakter, Strategi Membangun Kompetensi \& karakter guru. Yokjakarta: Pustaka pelajar.

Wong.HK., 2004. Induction program that keep new teacher teaching and improving. NASSP Bulletin; Proquest Tesearch Library. Vol. 88.(638): 41-55 